\title{
Chemical profiling, in vitro antimicrobial and antioxidant activities of pomegranate, orange and banana peel-extracts against pathogenic microorganisms
}

Safynaz Magdy Hanafy ${ }^{1 *}$, Yasser Mohamed Abd El-Shafea', Waleed Diaeddeen Saleh² and Hayam Mohamed Fathy ${ }^{2}$

\begin{abstract}
Background: The use of natural preservatives became of great interest; good examples of these natural preservation agents are plant peels. The use of plant peels has dual benefits; first is their antimicrobial activity against food-borne pathogens, while the second is minimizing agro-industrial wastes.

Results: The evaluation of the antimicrobial potential of both methanolic and ethanolic extracts of three fruit peels (orange, pomegranate, and banana), against 4 Gram-positive $\left(\mathrm{G}^{+}\right), 3 \mathrm{Gram}$-negative bacteria $\left(\mathrm{G}^{-}\right)$, and 2 fungal strains revealed that both pomegranate peel extracts exhibited significantly higher inhibitory effect on all tested $\mathrm{G}^{+}$ bacteria. Methanolic extract of pomegranate peel gave higher activity than the ethanolic one against $\mathrm{G}^{+}$and $\mathrm{G}^{-}$ bacteria except for S. typhimurium. Against A. flavus and A. niger, both pomegranate and orange extracts showed activity ranging between 65 and 100\% more than the positive control. The ethanolic extracts of all tested peels showed a considerable capacity of antioxidant compounds compared to the methanolic extracts. The highest antioxidant capacity was found for ethanolic and methanolic extracts of pomegranate, 66.870 and $56.262 \mathrm{mg} / \mathrm{ml}$, respectively. Generally, the concentration of total phenolic compounds was higher than that of total flavonoids followed by tannins. The highest readings of all tested constituents were reported for pomegranate extracts followed by orange and then banana. The total phenolic content, total flavonoids, and tannins were proportional to antioxidant values. GC-MS of pomegranate peel extracts identified 23 compounds in the methanolic extract versus 31 compounds in the ethanolic one. These components were identified based on their retention times and mass spectral fragmentation pattern. 5-hydroxymethylfufural (HMF) represented the major component in both methanolic and ethanolic extracts with peak area percentage of $65.78 \%$ and $48.43 \%$, respectively.

Conclusions: The results showed negative effect of methanolic and ethanolic extracts of pomegranate on $\mathrm{G}^{+}$and $\mathrm{G}^{-}$bacteria and two fungal pathogenic strains. The phytochemical analysis regarded these results to the high content of phenols, flavonoids, and tannins. GC-MS chromatogram identified many compounds known to be effective as antioxidants and antibacterial and antifungal agents. These indications show that pomegranate peel may be a superior natural food-preserver, but further studies about the suitable formulation, dosage, and possible side-effects are still needed.
\end{abstract}

Keywords: Antimicrobial activity, Pomegranate peel extracts, Phytochemical assay, GC-MS analysis

\footnotetext{
*Correspondence: magdys35@yahoo.com

${ }^{1}$ Regional Centre for Food and Feed (RCFF), Agriculture Research Center

(ARC), Giza, Egypt

Full list of author information is available at the end of the article
}

\section{Springer Open}

(c) The Author(s). 2021 Open Access This article is licensed under a Creative Commons Attribution 4.0 International License, which permits use, sharing, adaptation, distribution and reproduction in any medium or format, as long as you give appropriate credit to the original author(s) and the source, provide a link to the Creative Commons licence, and indicate if changes were made. The images or other third party material in this article are included in the article's Creative Commons licence, unless indicated otherwise in a credit line to the material. If material is not included in the article's Creative Commons licence and your intended use is not permitted by statutory regulation or exceeds the permitted use, you will need to obtain permission directly from the copyright holder. To view a copy of this licence, visit http://creativecommons.org/licenses/by/4.0/. 


\section{Background}

Food-borne illness due to consumption of food contaminated with pathogenic bacteria and/or their toxins is a vital concern to public health. The symptoms of such illness range from vomiting, nausea, and diarrhea to longterm diseases such as liver or kidney failure, cancer, and neural or brain disorders [1]. The most common bacteria causing food-borne illness are Escherichia coli, Staphylococcus aureus, Salmonella typhimurium, Listeria monocytogenes, Clostridium botulinum, Bacillus cereus, Vibrio parahaemolyticus, and others. Food poisoning is still a concern for both consumers and the food industry despite the use of various preservation methods. Food processors, food safety researchers, and regulatory agencies are continuously concerned with the high and growing number of illness outbreaks caused by some pathogenic and spoilage microorganisms in foods $[1,2]$.

In food industry, addition of synthetic or chemical agents like formaldehyde, sulfites, nitrates, sorbates, and benzoates and synthetic antioxidants are most widely used as preservatives. Although the use of such chemicals is efficient, it may cause severe side-effects due to their accumulation in the food chain that may affect human health. Thus, the food industry has aimed to move toward the ways of clean labeling and eliminate synthetic preservatives from food formulations and alternate them with natural preservatives [3-8].

In light of the evidence of the rapid prevalence of multi-drug-resistant isolates, the need to discover new antimicrobial agents is of excessive importance. Many plants have been used because of their antimicrobial activities against pathogenic microorganisms, which are due to phytochemicals synthesized in the secondary metabolism of the plant such as flavonoids, saponins, tannins, phenolic compounds, alkaloids, anthraquinones, glycosides, and reducing sugars [8-11].

Various studies conducted on fruit and vegetable peels revealed the presence of important constituents, which can be used for pharmacological or pharmaceutical purposes. Researchers extracted many components such as phenols, tannins, flavonoids, alkaloids, and saponins that have antimicrobial, antioxidant, and anti-inflammatory activities [8, 12, 13].

For centuries, orange (Citrus sinensis) peel is being used as a conventional and folkloric drug against a lot of illnesses like cancer, stomach ache, immune system diseases, diuretic, cold, vitamin deficiencies, and digestive system diseases as well as bacterial and viral infections $[14,15]$. Millions of tons of orange are produced globally, of which about 20\% are used as beverage in addition to sauces and dressings. The remaining peels are regarded as waste although the peel extracts of citrus are considered an origin of antioxidants, phenols, flavonoids, and antimicrobial agents $[16,17]$.
Gyawali and Ibrahim [18] reported that 30\% of the total banana production is disposed as wastes (peels). Banana (Musa acuminata) peels can be applied in various industries such as cosmetics, pulp, biosorbent, biofuel, organic fertilizers, paper, and environmental cleanup and can be used as conventional and inherent drug for healing many diseases [19-21].

Pomegranate (Punica granatum L.) fruit has been reported to exert a promising preventive activity against several inflammatory and chronic diseases. The main composition of pomegranate by-products as well as their potential to enhance specific functionalities in food applications has recently been reviewed by [22-24] who added pomegranate seed juice by-product (PSP) as reinforcing and antimicrobial agent to fish gelatin (FG) films as a promising eco-friendly active material for food packaging applications. Also, [25] stated that pomegranate has antifungal, insecticidal, antibacterial, anticoccidial, and molluscicidal effect against both plant and human pathogens.

The present study investigates the antimicrobial and antioxidant activities of local orange (Citrus sinensis, var. common Balady), pomegranate (Punica granatum, var. Wonderful), and banana (Musa acuminate, var. Grand nan) peel extracts against nine pathogenic microbial strains. Furthermore, this research also aims to study the phytochemical composition of the peel extracts as well as to determine the bioactive components of the most promising extracts.

\section{Methods}

\section{Plant material and extraction}

Three fresh fruits belonging to different families were purchased from the Egyptian local market. These fruits were orange (Citrus sinensis, var. common Balady), pomegranate (Punica granatum, var. Wonderful), and banana (Musa acuminate, var. Grand nan). The fruit taxonomic identities were confirmed by the Department of Pomology, Faculty of Agriculture. The fruits were washed with running tap water followed by sterilized distilled water and then peeled. The fruit peels were dried in the oven at $40{ }^{\circ} \mathrm{C}$ for $24 \mathrm{~h} \mathrm{[26]}$. The dried peels of all fruits were ground to fine powder and stored at 4 ${ }^{\circ} \mathrm{C}$.

Ethanol and methanol were separately used to extract the bioactive compounds from the three fruit peels. One hundred grams of each powdered peel was extracted with $900 \mathrm{ml}$ of each solvent separately and shaked for 3 days at room temperature [27]. The extracts were filtered using Whatman No. 1 filter paper. The filtrates were concentrated by evaporating the solvents using a rotary evaporator [28]. Each dry film was dissolved in $10 \%$ DMSO, filter-sterilized $(0.45 \mu \mathrm{m})$, stored in dark bottles, and refrigerated at $4{ }^{\circ} \mathrm{C}$ for further use. 
Test microorganisms and microbial suspensions

Nine microorganisms were used to test the antimicrobial activity of peel extracts. These test microorganisms included 4 Gram-positive bacteria, i.e., Bacillus cereus ATCC 33018, Staphylococcus aureus ATCC 25923, Staphylococcus aureus (MRSA) ATCC 43300, and Listeria monocytogenes ATCC 7644, along with 3 Gramnegative bacteria, i.e., Pseudomonas aeruginosa ATCC 9027, Escherichia coli ATCC 35218, and Salmonella typhi ATCC 14028, whereas the two tested fungal strains were Aspergillus niger ATCC 16888 and Aspergillus flavus ATCC 16883.

All test microbes were inoculated in Mueller-Hinton agar [29] and incubated at their optimum temperatures for 24-48h. A loopful of each tested strain was subcultured into $5 \mathrm{ml}$ Mueller-Hinton broth medium and then incubated for $18-24 \mathrm{~h}$ to be used for the antimicrobial studies.

\section{Antimicrobial studies}

According to [30], well diffusion technique was used to evaluate the antimicrobial activity of each fruit peel extract against the tested pathogenic strains. Melted Mueller-Hinton agar (MHA) was inoculated with an 1824-h-old broth culture of each tested strain and poured into Petri plates then kept to solidify. A sterile borer was used to make 8-mm wells in each Petri plate. The wells were loaded with $50 \mu \mathrm{l}$ of each extract, separately. Wells of the negative control plates were loaded with DMSO, while the positive control was represented by antibiotic disks. Ampicillin was used against Gram-negative bacteria, kanamycin was used against Gram-positive bacteria, and Nystatin was used against fungi. All treatments were conducted in triplicates and all plates were incubated for $24-48 \mathrm{~h}$ at $30-37{ }^{\circ} \mathrm{C}$. After incubation, the zones of inhibition were recorded.

For quantification, plant extracts that gave positive results for the well diffusion assay were used to determine their minimum inhibitory concentration (MIC) following the same assessment method and medium. MIC is the lowest concentration of the tested extracts that gave zone of inhibition against pathogenic strains. Different concentrations of pomegranate peel extract were prepared as $1.25,2.5,5$, and $10 \% \mathrm{w} / \mathrm{v}$, while for both banana and orange peel extracts were as follows: 10, 20, and $30 \% \mathrm{w} / \mathrm{v}$. The zones of inhibition were recorded for the different concentrations [28].

\section{Total antioxidant capacity assay}

The total antioxidant capacity of the methanolic and ethanolic extracts was evaluated by the phosphomolybdenum method according to [31]. $0.3 \mathrm{ml}$ extract was combined with $3 \mathrm{ml}$ of reagent solution $(0.6 \mathrm{M}$ sulfuric acid, $28 \mathrm{mM}$ sodium phosphate, and $4 \mathrm{mM}$ ammonium molybdate). The tubes were capped and incubated in a thermal block at $95{ }^{\circ} \mathrm{C}$ for $90 \mathrm{~min}$. After cooling to room temperature, the absorbance of the reaction mixture was measured at $695 \mathrm{~nm}$ using a spectrophotometer (Specor D250 plus-Analytik Jena) against a blank of methanol or ethanol. Total antioxidant capacity was expressed in ascorbic acid equivalent per gram dry extract.

\section{Phytochemical assay}

Three classes of phytochemicals (tannins, phenolic compound, and flavonoids) were traced in the used peel extracts. These determinations were conducted at The Regional Centre for Food and Feed of The Agricultural Research Centre by standard qualitative methods described by [32-34]. All methods were optimized with a positive control.

Gas chromatography-mass spectrometry (GC-MS) analysis The chemical composition of the most potent ethanolic and methanolic peel extracts, i.e., pomegranate, was determined according to [35], using Trace GC1310-ISQ mass spectrometer (Thermo Scientific, Austin, TX, USA). The mass spectrometer had a direct capillary column TG-5MS $(30 \mathrm{~m} \times 0.25 \mathrm{~mm} \times 0.25 \mu \mathrm{m}$ film thickness). Helium was used as a carrier gas at a constant flow rate of $1 \mathrm{ml} / \mathrm{min}$. EI mass spectra were collected at $70 \mathrm{eV}$ ionization voltages over the range of $\mathrm{m} / \mathrm{z} 50-500$ in full scan mode. The ion source temperature was set at $200{ }^{\circ} \mathrm{C}$. The components were identified by comparison of their retention times and mass spectra with those of WILEY 09 and NIST 11 mass spectral database.

\section{Statistical analysis}

All determinations were conducted in triplicates and were treated by two-way analysis of variance (ANOVA); the mean values were compared by LSD $(P \leq 0.01)$ using IBM SPSS, ver. 20.

\section{Results}

Antimicrobial activity

The inhibitory effect of ethanolic and methanolic extracts of the citrus and pomegranates as well as banana peels were estimated against four Gram-positive $\left(\mathrm{G}^{+}\right)$ and three Gram-negative bacteria $\left(G^{-}\right)$pathogenic bacteria along with two pathogenic fungal strains. DMSO was used as negative control, while positive controls were kanamycin, ampicillin, and nystatin, in that order. The overall results are illustrated in Fig. 1.

\section{Gram-positive bacteria}

The antimicrobial tests of the three used fruit peels against B. cereus, S. aureus MRSA, S. aureus, and $L$. monocytogenes revealed that both pomegranate peel extracts exhibited the most significant inhibitory effect on 


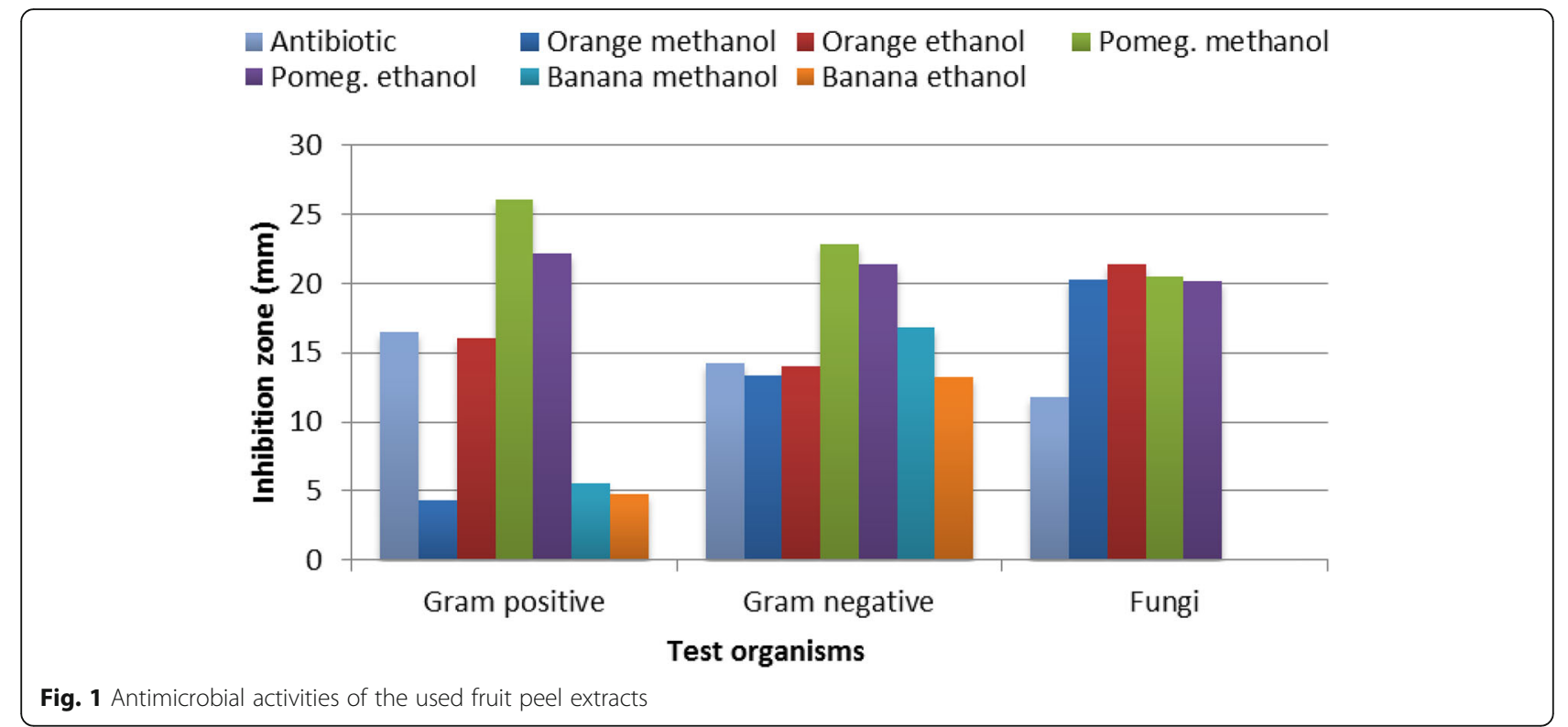

the tested strains compared to both the treatments and the positive control, except for kanamycin against $B$. cereus in the case of ethanolic extract (Table 1).

Methanolic extract of pomegranate peel gave the highest activity against all tested stains especially $S$. aureus (MRSA) and S. aureus. In the same direction, but with a little less potency, ethanolic extract of pomegranate peel showed antibacterial activity against all tested strains with special reference to $S$. aureus. Bacillus cereus showed sensitivity against both methanolic and ethanolic orange peel extracts while both banana peel extracts significantly affected $S$. aureus (MRSA).

\section{Gram-negative bacteria}

Again, the methanolic extract of pomegranate peel gave the highest antibacterial activity against Gramnegative bacteria (20.3-25.0 mm) compared to Ampicillin (12.0-18.3 mm). Pseudomonas aeruginosa was found to be the most sensitive tested bacterium. Pomegranate peel ethanolic extract showed a significant inhibitory effect against $S$. typhimurium $(25 \mathrm{~mm})$ followed by both its methanolic extract and the ethanolic extract of orange peels with equal inhibition zones of $23.3 \mathrm{~mm}$. The ethanol extract of banana peels and methanolic extract of pomegranate peels gave similar antibacterial effect against E. coli $(20.3 \mathrm{~mm})$ and still, significantly, higher than control (Table 2).

Compared to the positive control, both banana peel extracts did not show significant effects against $S$. typhimurium. For E. coli, results reflected that banana peel ethanol extract had a significant inhibitory effect $(20.3 \mathrm{~mm})$ similar to pomegranate methanolic extract, whereas the methanolic extract of banana peel showed inhibitory effect against $P$. aeruginosa, significantly higher than the positive control, but still significantly lower than both the methanolic and ethanolic extracts of pomegranate peel. Many pathogens were not affected by either methanolic or ethanolic extracts of orange or banana peels.

Table 1 Inhibition zones of both methanolic and ethanolic extracts of the used fruit peels against some $\mathrm{G}^{+}$food pathogens

\begin{tabular}{|c|c|c|c|c|c|c|c|}
\hline \multirow[t]{3}{*}{ Strain } & \multicolumn{7}{|l|}{ Fruit peel } \\
\hline & \multicolumn{2}{|l|}{ Orange $^{a}$} & \multicolumn{2}{|c|}{ Pomegranate $^{a}$} & \multicolumn{2}{|l|}{ Banana $^{a}$} & \multirow[t]{2}{*}{$(+)^{b}$ Cont. } \\
\hline & $\bar{M}$ & $\mathrm{E}$ & $\bar{M}$ & $\mathrm{E}$ & $\bar{M}$ & $E$ & \\
\hline B. cereus & $17.3 \pm 0.1$ & $16.0 \pm 0.1$ & $24.3 \pm 0.1$ & $21.0 \pm 0.1$ & - & - & 21.1 \\
\hline S. aureus & - & - & $26.3 \pm 0.1$ & $24.0 \pm 0.3$ & - & - & 20.0 \\
\hline S. aureus (MRSA) & - & - & $27.3 \pm 0.2$ & $24.0 \pm 0.2$ & $22 \pm 0.3$ & $19 \pm 0.2$ & 14.0 \\
\hline L. monocytogenes & - & - & $26.3 \pm 0.1$ & $19.7 \pm 0.1$ & - & - & 11.0 \\
\hline \multicolumn{8}{|c|}{$\mathrm{LSD}_{0.01}=1.741 ; \mathrm{CV}=6.941 \%$} \\
\hline
\end{tabular}

Results are the means \pm standard deviation

aZone of inhibition in millimeters

$M$ methanol, $E$ ethanol, $(+)^{\mathrm{b}}$ Cont. positive control 
Table 2 Inhibition zones of both methanolic and ethanolic extracts of the used fruit peels against some $\mathrm{G}^{-}$food pathogens

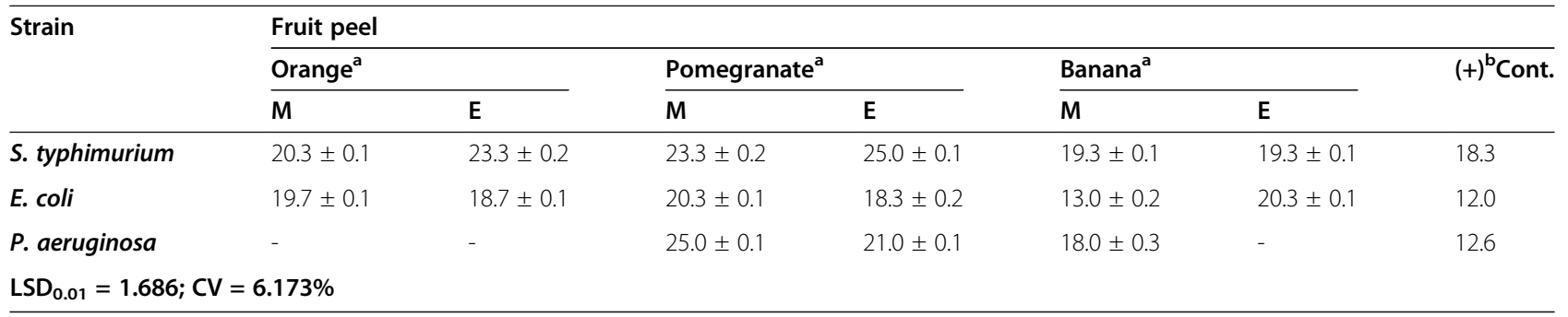

Results are the means \pm standard deviation

aZone of inhibition in millimeters

$M$ methanol, $E$ ethanol, $(+)^{\mathrm{b}}$ Cont. positive control

\section{Fungal strains}

The extracts of fruit peels gave promising results against both fungal strains. In this study, A. niger and A. flavus were inhibited by orange and pomegranate peel extracts. Data in Table 3 show that, in comparison with positive control, $A$. niger was significantly affected by both ethanolic and methanolic extracts of orange peel followed by methanolic and ethanolic extracts of pomegranate, respectively; their inhibition zones ranged from 22.7 to $20.0 \mathrm{~mm}$. On the other hand, the orange and pomegranates peel extracts had almost the same inhibitory effect against A. flavus which was about $65 \%$ more than the positive control.

These results revealed that there was no antifungal activity of banana extracts against both fungal strains.

\section{Minimum inhibitory concentration (MIC)}

For a quantitative view, the MIC of all used peel extracts against all tested microbes is illustrated in Fig. 2. Inhibition zones and MIC values are known for determination of antimicrobial activity.

The MIC values of pomegranate peel extracts ranged between 6.25 and $12.5 \mathrm{mg} / \mathrm{ml}$ against all tested organisms, while orange and banana peel extracts showed higher values of MIC than pomegranate peel extracts against all tested microbes ( 75 to $300 \mathrm{mg} / \mathrm{ml}$ ). Figure 2 shows that the least value of MIC $(6.25 \mathrm{mg} / \mathrm{ml})$ was given by methanolic pomegranate peel extract on all tested microbes except for S. aureus, Salmonella typhimurium, and Aspergillus flavus to which it was $12.5 \mathrm{mg} /$ $\mathrm{ml}$. For the ethanolic pomegranate peel extract, the least
MIC values $(6.25 \mathrm{mg} / \mathrm{ml})$ were achieved only versus $S$. aureus and Salmonella typhimurium, whereas it was $12.5 \mathrm{mg} / \mathrm{ml}$ versus all the other tested microorganisms. These results indicated the superiority of pomegranate peel in both methanolic and ethanolic extracts.

\section{Total antioxidant capacity}

The assay depended on the reduction of $\mathrm{Mo}(\mathrm{VI})$ to $\mathrm{Mo}(\mathrm{V})$ by the antioxidant compounds in samples and formation of a green phosphate/Mo(V) complex. Table 4 presents the total antioxidant capacity of the different extracts of the used fruit peels. The ethanol extracts of the different fruit peels showed a considerable capacity of antioxidant compounds compared to the methanolic extracts.

The highest antioxidant capacity was found for ethanolic and methanolic extracts of pomegranate, 66.870 and $56.262 \mathrm{mg} \mathrm{AAE} / \mathrm{g}$, respectively. Both orange peel extracts showing higher antioxidant levels (41.23 and 38.97 mg AAE/g) respectively than those of banana peel extracts.

\section{Phytochemical assessment}

Out of the three phytochemicals tested, phenolic compounds and total flavonoids were present in all plant extracts, while tannins were found in only four fruit extracts (Fig. 3). The highest readings of all three tested constituents were reported for pomegranate extracts, followed by orange and then banana. In all plant extracts, the concentration of total phenolic compounds

Table 3 Inhibition zones of both methanolic and ethanolic extracts of the used fruit peels against some fungal food pathogens

\begin{tabular}{|c|c|c|c|c|c|c|c|}
\hline \multirow[t]{3}{*}{ Strain } & \multicolumn{7}{|l|}{ Fruit peel } \\
\hline & \multicolumn{2}{|l|}{ Orange $^{a}$} & \multicolumn{2}{|c|}{ Pomegranate $^{a}$} & \multicolumn{2}{|c|}{ Banana $^{a}$} & \multirow[t]{2}{*}{$(+)^{b}$ Cont. } \\
\hline & $M$ & $\mathrm{E}$ & $M$ & $\mathrm{E}$ & $M$ & $\mathrm{E}$ & \\
\hline A. niger & $22.3 \pm 0.2$ & $22.7 \pm 0.1$ & $21.0 \pm 0.2$ & $20.0 \pm 0.1$ & - & - & 10.6 \\
\hline A. flavus & $18.3 \pm 0.2$ & $20.0 \pm 0.1$ & $20.0 \pm 0.2$ & $20.3 \pm 0.3$ & - & - & 13.0 \\
\hline \multicolumn{8}{|c|}{$\mathrm{LSD}_{0.01}=1.485 ; \mathrm{CV}=6.585 \%$} \\
\hline
\end{tabular}

Results are the means \pm standard deviation

azone of inhibition in millimeters

$M$ methanol, $E$ ethanol, $(+)^{\mathrm{b}}$ Cont. positive control 


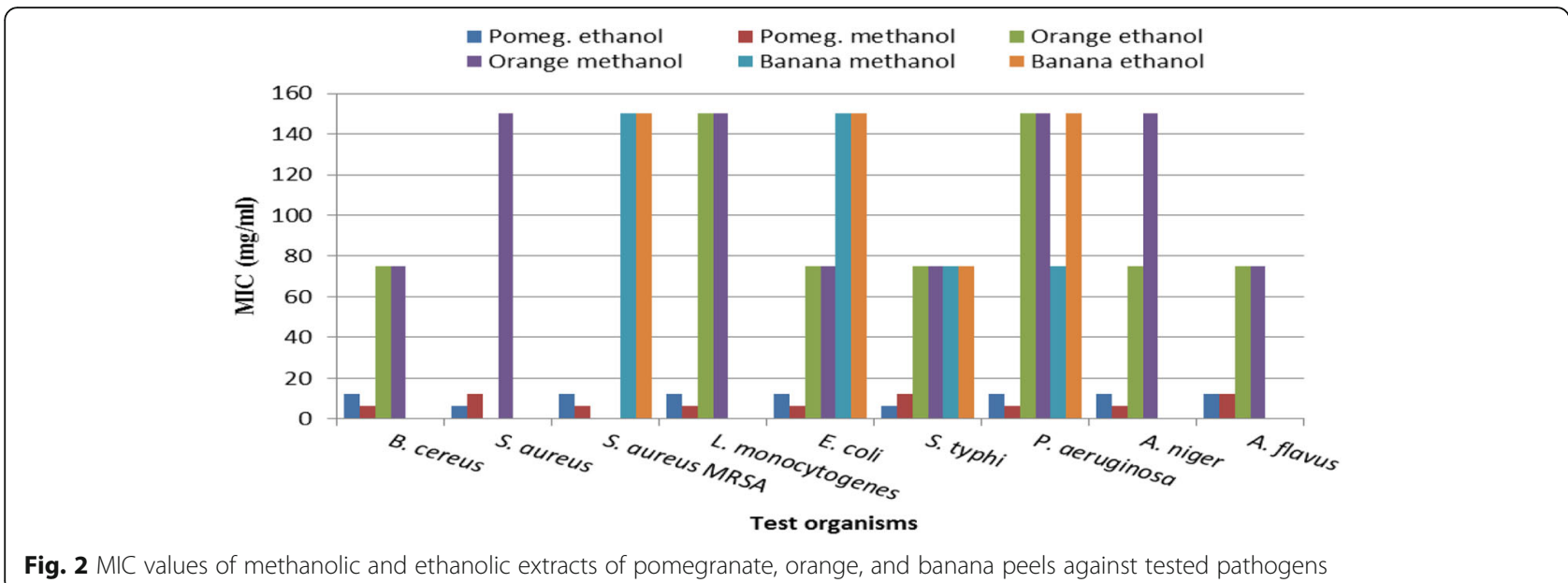

Fig. $2 \mathrm{MIC}$ values of methanolic and ethanolic extracts of pomegranate, orange, and banana peels against tested pathogens

was higher than the concentration of total flavonoids followed by tannins.

It is observed that extraction of the bioactive compounds from pomegranate using methanolic was more efficient than using ethanolic.

\section{GC-MS analysis of pomegranate peel extracts}

As the previous results indicated the superiority of pomegranate peel extracts, they were subjected to qualitative analysis by GC-MS. The chromatograms, in Fig. 4, showed that 23 compounds were identified in the methanolic extract versus 31 compounds in the ethanolic one. These components were identified qualitatively based on their retention times and mass spectral fragmentation pattern.

The results (Table 5) reflect that 5hydroxymethylfufural (HMF) represented the major component in both methanolic and ethanolic extracts with peak area percentage of $65.78 \%$ and $48.43 \%$, respectively. Trioxsalen was recorded with peak area percentage of $4.87 \%$ and $7.52 \%$ in methanolic and ethanolic extracts, respectively. Also, 4H-Pyran-4-one, 2, 3dihydro-3, 5-dihydroxy-6-methyl- was identified in both the methanolic extract (4.17\%) and the ethanolic extract $(4.55 \%)$.

Table 4 Total antioxidant capacity of the used fruit peel extracts

\begin{tabular}{lll}
\hline Fruit & \multicolumn{2}{l}{ Extracts $(\mathbf{m g ~ A A E} / \mathbf{g})$} \\
\cline { 2 - 3 } & Ethanolic & Methanolic \\
\hline Pomegranate & $66.87 \pm 0.05$ & $56.26 \pm 0.04$ \\
Orange & $41.23 \pm 0.07$ & $38.97 \pm 0.06$ \\
Banana & $23.86 \pm 0.05$ & $21.86 \pm 0.05$ \\
\hline
\end{tabular}

mg AAE/g milligram ascorbic acid equivalent/gram (dry weight)

\section{Discussion}

The antimicrobial effect of ethanolic and methanolic pomegranate peel extracts reported in this study was previously reported by several authors [28, 36-39]. With respect to $\mathrm{G}^{+}$bacteria, our study is in line with others that reported the superiority of the methanolic pomegranate peel extract over the ethanolic one [36-39].

Concerning $G^{-}$bacteria, previous studies reported the activity of methanolic, ethanolic, and aqueous extract of pomegranate peel, with even better results than these of the standard antibiotic [28, 38-42].

Compared to pomegranate ethanol extract, the methanolic extract showed the greatest antimicrobial activities against different pathogens [43, 44]. Also, [45] recorded that the ethanol extract of Musa sapientum peel can be used to control infections caused by Saalmonella typhi and $E$. coli, our study showed that many pathogens were not affected by neither methanolic nor ethanolic extracts of orange or banana peels. Saleem and Saeed and $\mathrm{Al}$ Laham et al. $[13,46]$ stated that the resistance of Gramnegative bacteria against antibacterial substances may be due to outer phospholipid-membrane carrying the structural lipopolysaccharide components, which make it impermeable to lipophilic solutes, and porins constitute a selective barrier to the hydrophilic solutes.

Contrary to our study, [47] studied the antifungal activity of banana peel extracts against A. niger, A. flavus, and Penicillium. They found that the extract of dried banana peel powder exhibited antifungal activity against $A$. niger. The results in this study were in consistency with researchers who reported the significant inhibitory effect of $C$. sinensis and Punica granatum $L$ peel extract on the growth of F. oxysporum, P. citrinum, A. niger, F. verticillioides, and A. flavus [13, 48, 49].

The antimicrobial effect of the fruits peels extracts in our study may be attributed to the presence of antimicrobial compounds in the plants such as antioxidants, 


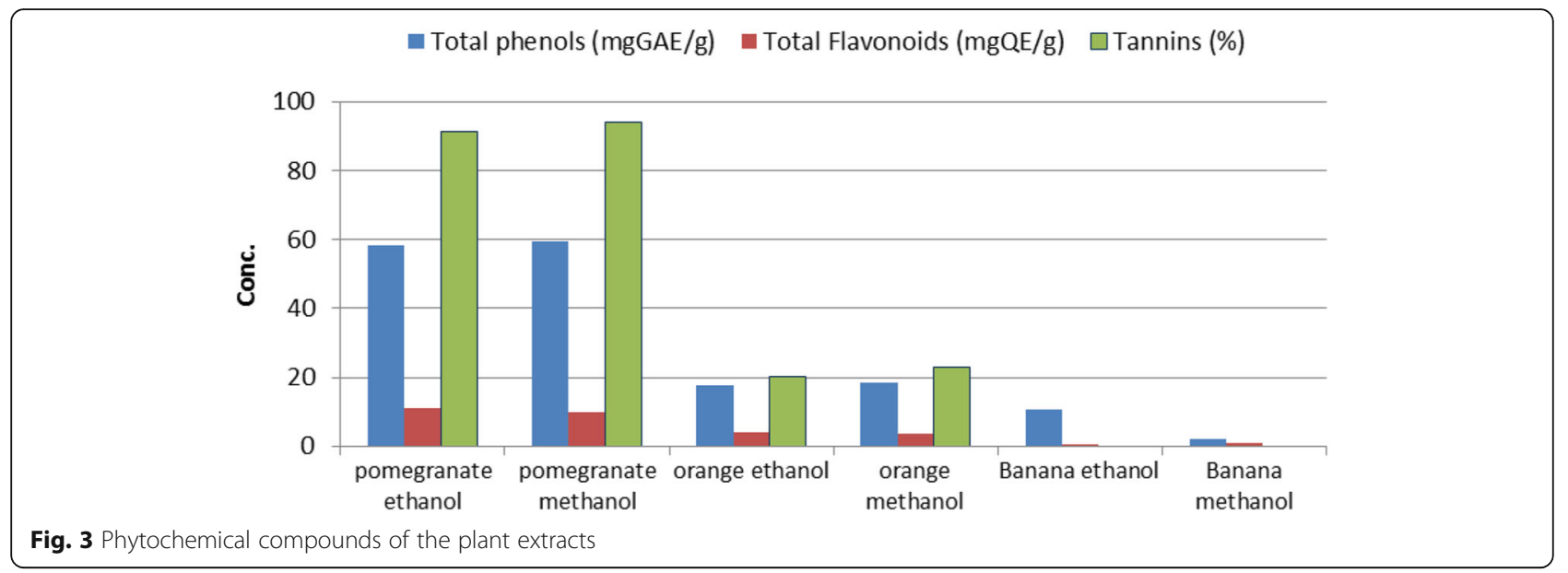

phenols, flavonoids, tannins, and also the presence of secondary metabolites. Therefore, the antimicrobial activities differ from one plant extract to another due to the variance mode of action beyond their chemical composition $[14,50]$. There are a lot of factors that can influence the antimicrobial activity of different fruit peel extracts. These factors such as the freshness of the used peels, the extraction method and the solvent, the country where the used plant was grown, and the time when the plant was cultivated [4].

With respect to total antioxidant capacity, the present study was in line with the findings of [45] but contradicts with the results of [51] which indicated that methanolic extract gave better results than ethanolic one using banana peels. The results of [52] indicated that the solvent used for extraction may have different impact on the antioxidant capacity of the extracts.

The superior antioxidant capacity found, in this study, for ethanol and methanolic extract of pomegranate may be regarded to the presence of total tannins and purified constituents as reported earlier by [53, 54]. Our results are in line with those of [55] who examined the antioxidant activity of nine different pomegranate peels and pulp. They found that the antioxidant activity of pomegranate peel extract was 10 times higher than the pulp extract. The results of [56] demonstrated that the pomegranate pericarp of Shahvar cultivar, which represented the highest phenolic compounds, showed the greatest antioxidant activity. In the same direction, [57] reported the higher antioxidant capacity of pomegranate peel extract compared to its seeds.

Both orange peel extracts showing higher antioxidant levels than those of banana peel extracts in this study match which with the findings of [53]. The antioxidant activity of orange peels may be regarded to glycosylated flavonoids such as hespridin and naringin [58]. The antioxidant activity of orange peel extracts was reported by [53] and regarded to the presence of various compounds, e.g., gallocatechin [59] and dopamine [60]. Wolfe et al. [61] attributed the differences in the antioxidant activities among the fruits to their differences in phenolic contents and compositions and to other non-phenolic antioxidants present in the samples.
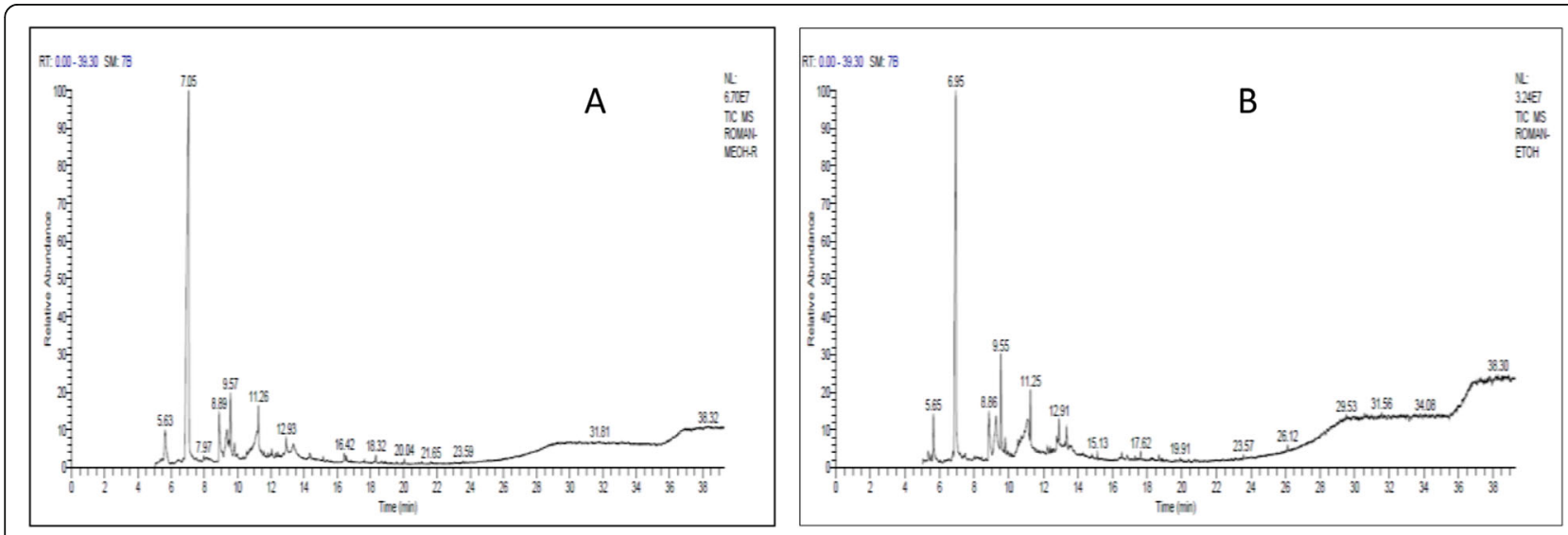

Fig. 4 GC-MS chromatogram of methanolic (a) and ethanolic (b) extracts of pomegranate peels 
Table 5 The most abundant chemical compounds in extracts of pomegranate peels by GC-MS analysis

\begin{tabular}{|c|c|c|c|c|}
\hline Active compound & RT & Area\% & M.F & M.W \\
\hline \multicolumn{5}{|l|}{ Pomegranate peel methanolic extract } \\
\hline 4H-Pyran-4-one,2,3-dihydro-3,5-dihydroxy-6-methyl & 5.63 & 4.17 & $\mathrm{C}_{6} \mathrm{H}_{8} \mathrm{O}_{4}$ & 144 \\
\hline 5-Hydroxymethylfurfural & 7.04 & 65.78 & $\mathrm{C}_{6} \mathrm{H}_{6} \mathrm{O}_{3}$ & 126 \\
\hline 1,2,3,8,9,11a-hexahydro-3a,8-m ethano-9-methyl-3ah-cyclopentacyclodecene & 8.89 & 4.79 & $\mathrm{C}_{15} \mathrm{H}_{20}$ & 200 \\
\hline Pyrrolidine, 1-(1,6-dioxooctadecyl)- & 9.35 & 3.44 & $\mathrm{C}_{22} \mathrm{H}_{41} \mathrm{NO}_{2}$ & 351 \\
\hline Trioxsalen & 9.57 & 4.87 & $\mathrm{C}_{14} \mathrm{H}_{12} \mathrm{O}_{3}$ & 228 \\
\hline 1,4-benzenediol,2-(1,1-dimethylethyl)-5-(2-propenyl)- & 11.26 & 5.28 & $\mathrm{C}_{13} \mathrm{H}_{18} \mathrm{O}_{2}$ & 206 \\
\hline \multicolumn{5}{|l|}{ Pomegranate peel ethanolic extract } \\
\hline 4H-Pyran-4-one,2,3-dihydro-3,5-dihydroxy-6-methyl- & 5.65 & 4.55 & $\mathrm{C}_{6} \mathrm{H}_{8} \mathrm{O}_{4}$ & 144 \\
\hline 5-Hydroxymethylfurfural & 6.95 & 48.34 & $\mathrm{C}_{6} \mathrm{H}_{6} \mathrm{O}_{3}$ & 126 \\
\hline Malononitrile,(2-hydroxy-3-methoxybenzylidene)- & 8.86 & 6.69 & $\mathrm{C}_{11} \mathrm{H}_{8} \mathrm{~N}_{2} \mathrm{O}_{2}$ & 200 \\
\hline Octadecanoic acid, 2-propenyl ester & 9.27 & 6.51 & $\mathrm{C}_{21} \mathrm{H}_{40} \mathrm{O}_{2}$ & 324 \\
\hline Trioxsalen & 9.55 & 7.52 & $\mathrm{C}_{14} \mathrm{H}_{12} \mathrm{O}_{3}$ & 228 \\
\hline Xanthosine & 11.10 & 4.06 & $\mathrm{C}_{10} \mathrm{H}_{12} \mathrm{~N}_{4} \mathrm{O}_{6}$ & 284 \\
\hline 3,4-Dihydro-2h-1,5-(3"-t-butyl)benzodioxepine & 11.25 & 3.31 & $\mathrm{C}_{13} \mathrm{H}_{18} \mathrm{O}_{2}$ & 206 \\
\hline à-D-glucopyranoside, methyl 2-(acetylamino)-2-deoxy-3-o-(trimethylsilyl)-,cyclic methylboronate & 12.91 & 2.42 & $\mathrm{C}_{13} \mathrm{H}_{26} \mathrm{BNO}_{6} \mathrm{Si}$ & 331 \\
\hline á-D-Galactopyranoside, methyl 2,6-bis-O-(trimethylsilyl)-, cyclic methylboronate & 13.33 & 2.09 & $\mathrm{C}_{14} \mathrm{H}_{31} \mathrm{BO}_{6} \mathrm{Si}_{2}$ & 362 \\
\hline
\end{tabular}

In phytochemical assay, our study matches with [56] who reported that the methanol extract of different varieties of pomegranate had the highest phenolic content. The total phenolic content, total flavonoids, and tannins showed a proportional relationship with antioxidant values, as already observed by other authors [62]. The total phenolic content of methanolic and ethanolic extract of orange peels in this study (18.61 and 17.704 $\mathrm{mg} \mathrm{GAE} / \mathrm{ml}$ ) was higher than that of [51] for the same extract (12.5 and $10.25 \mathrm{mg} \mathrm{GAE} / \mathrm{ml})$. The extracts of banana peels were found to contain both phenolic compounds and flavonoids which is in line with the study of [45]. The present determinations did not show tannins in banana peel extracts contradicting the results of the same previously mentioned authors.

For GC-MS analysis, [63] mentioned that 5hydroxymethylfufural has antioxidant activity while $4 \mathrm{H}$ Pyran-4-one,2,3-dihydro-3,5-dihydroxy-6-methyl- has antioxidant, antimicrobial, laxative, and anticancer activities. In the same direction, the results of [64] showed bactericidal activity of HMF against a broad spectrum of bacteria with variable degrees. The antifungal activity of the pomegranate extracts is probably regarded to $4 \mathrm{H}$ Pyran-4-one, 2, 3-dihydro-3, 5-dihydroxy-6-methyl compound as previously reported [65].

For the ethanolic extract of pomegranate peel components, [66, 67] reported antibacterial and antifungal activities of malononitrile while the antibacterial activity of Octadecanoic acid, 2-propenyl ester was reported by [68]. Pyrrolidine, a component of the methanolic extract of pomegranate peels in this study, was found to bear antibacterial and antifungal activities $[69,70]$.

\section{Conclusion}

The present study is reporting the antimicrobial potential of three fruit peel extracts to benefit from their activity as natural preservatives. The results demonstrated the effect of methanolic and ethanolic peel extracts of pomegranate against Gram-positive, Gram-negative, and two fungal pathogenic strains. The phytochemical analysis confirmed these results by finding high content of phenols, flavonoids, and tannins in these extracts. The GC-MS chromatograms identified many compounds that are known to be effective as antioxidant, antibacterial, and antifungal agents. The indications clearly show that pomegranate peel may be a superior natural foodpreserver, but further studies about the suitable formulation, dosage, and possible side-effects are still needed.

\section{Abbreviations \\ $\mathrm{G}^{+}$: Gram-positive bacteria; $\mathrm{G}^{-}$: Gram-negative bacteria; ATCC: American type culture collection; MRSA: Methicillin-resistant Staphylococcus aureus; MIC: Minimal inhibitory concentration; GC-MS: Gas chromatography-mass spectrometry}

\section{Acknowledgements}

Not applicable.

\section{Authors' contributions}

SMH conducted the practical work and prepared the manuscript. YMA and HMF participated in the experimental work and contributed to the manuscript preparation. SWD designed and supervised the study and revised the manuscript. All the authors have read approved the manuscript. 


\section{Funding}

Not applicable.

\section{Availability of data and materials}

The data from the study is publicly available.

\section{Declarations}

\section{Ethics approval and consent to participate}

Not applicable.

\section{Consent for publication}

All the authors approve the manuscript for publication.

\section{Competing interests}

The authors declare there are no competing interests.

\section{Author details}

${ }^{1}$ Regional Centre for Food and Feed (RCFF), Agriculture Research Center (ARC), Giza, Egypt. ${ }^{2}$ Department of Microbiology, Faculty of Agriculture, Cairo University, Giza, Egypt.

\section{Received: 26 January 2021 Accepted: 18 March 2021}

\section{Published online: 30 May 2021}

\section{References}

1. Erhabor CR, Erhabor JO, Mcgaw LJ (2019) The potential of South African medicinal plants against microbial biofilm and quorum sensing of foodborne pathogens: a review. South Afr J Bot 126:214-231

2. Abdel-raouf N, Mohamed H, Samah SM, Ibraheem I (2017) Controlling of microbial growth by using cystoseirabarbata extract. Egypt J Bot 57(3):469477

3. Hussain KA, Tarakji B, Kandy BPP, John J, Mathews J, Ramphul V, Divakar DD (2015) Antimicrobial effects of citrus sinensis peel extracts against periodontopathic bacteria: an in vitro study. Roczniki państwowego zakładu higieny 66(2):173-178

4. Pal J, Raju CV, Pandey G, Shukla BN (2018) Antimicrobial activity of pomegranate and orange peels extracts against selected food borne pathogens. Pharma Innov J 7(4):176-178

5. Pisoschi AM, Pop A, Georgescu C, Turcuş V, Olah NK, Mathe E (2018) An overview of natural antimicrobials role in food. Eur J Med Chem 143:922935. https://doi.org/10.1016/j.ejmech.2017.11.095

6. Thorat ID, Jagtap DD, Mohapatra D, Joshi DC, Sutar RF, Kapdi SS (2013) Antioxidants, their properties, uses in food products and their legal implications. Int J Food Stud 2(1):81-104

7. Gedikoğlu A, Sökmen M, Çivit A (2019) Evaluation of thymus vulgaris and thymbra spicata essential oils and plant extracts for chemical composition antioxidant, and antimicrobial properties. Food Sci Nutr 7(5):1704-1714. https://doi.org/10.1002/fsn3.1007

8. Alizadeh Behbahani B, Falah F, Lavi Arab F, Vasiee M, Tabatabaee Yazdi F (2020) Chemical composition and antioxidant, antimicrobial, and antiproliferative activities of Cinnamomum zeylanicum bark essential oil. Evid Based Complement Altern Med 2020:5190603-5190608. https://doi.org/1 $0.1155 / 2020 / 5190603$

9. De Zoysa MH, Rathnayake H, Hewawasam RP, Wijayaratne W (2019) Determination of in vitro antimicrobial activity of five sri lankan medicinal plants against selected human pathogenic bacteria. Int J Microbiol 5:1-8

10. Manandhar S, Luitel S, Dahal RK (2019) In vitro antimicrobial activity of some medicinal plants against human pathogenic bacteria. J Trop Med $5: 1-5$

11. Alizadeh BB, Noshad M, Falah F (2019) Cumin essential oil: phytochemical analysis, antimicrobial activity and investigation of its mechanism of action through scanning electron microscopy. Microbial Pathogen 136:103716. https://doi.org/10.1016/j.micpath.2019.103716

12. Alizadeh Behbahani B, Yazdi FT, Shahidi F, Noorbakhsh H, Vasiee A, Alghooneh A (2017) Phytochemical analysis and antibacterial activities extracts of mangrove leaf against the growth of some pathogenic bacteria. Microbial Pathogen 114:225-232

13. Saleem M, Saeed MT (2020) Potential application of waste fruit peels (orange, yellow lemon and banana) as wide range natural antimicrobial agent. J King Saud Univ Sci 32(1):805-810. https://doi.org/10.1016/j.jksus.201 9.02 .013

14. Shetty $S B$, Mahin-syed-ismail $P$, Varghese $S$, Thomas-george B, Kandathilthajuraj P, Baby D, Devang-divakar D (2016) Antimicrobial effects of citrus sinensis peel extracts against dental caries bacteria: an in vitro study. J Clin Exp Dent 8(1):e71

15. Yerou KO, Ibri K, Bouhadi D, Hariri A, Meddah B, Touil AT (2017) The use of orange (citrus sinensis) peel as antimicrobial and anti-oxidant agents. J Fund Appl Sci 9(3):1351-1357. https://doi.org/10.4314/jfas.v9i3.7

16. Hasija S, Ibrahim G, Wadia A (2015) Antimicrobial activity of Citrus sinensis (orange), Citrus limetta (sweet lime) and Citrus limon (lemon) peel oil on selected food borne pathogens. Int J Life Sci Res 3:35-39

17. Chung D, Cho TJ, Rhee MS (2018) citrus fruit extracts with carvacrol and thymol eliminated 7-log acid-adapted Escherichia coli 0157: h7, Salmonella typhimurium, and Listeria monocytogenes: a potential of effective natural antibacterial agents. Food Res Int 107:578-588. https://doi.org/10.1016/j. foodres.2018.03.011

18. Gyawali R, Ibrahim SA (2014) Natural products as antimicrobial agents. Food Contr 46:412-429. https://doi.org/10.1016/j.foodcont.2014.05.047

19. Kapadia SP, Pudakalkatti PS, Shivanaikar S (2015) Detection of antimicrobial activity of banana peel (musa paradisiaca I.) On porphyromonas gingivalis and aggregatibacter actinomycetemcomitans: an in vitro study. Contemp Clin Dent 6(4):496-499

20. Naikwade PV, Gaurav S, Sharayu D, Kailas I (2015) Evaluation of antibacterial properties of musa paradisiaca I . Leaves. Biosci Discov 6(1-i):80-84

21. Behiry SI, Okla MK, Alamri SA, El-hefny M, Salem MZ, Alaraidh IA, Salem AZ (2019) Antifungal and antibacterial activities of musa paradisiaca I. Peel extract: hplc analysis of phenolic and flavonoid contents. Processes 7(4):215

22. Akbar M, Song BJ, Essa MM, Khan MA (2015) Pomegranate: an ideal fruit for human health. Int J Nutr Pharmacol Neurol Dis 5(4):141-143

23. Andrade Mariana A, Lima V, Silva ANAS, Fernanda V, Castilho Maria C, Khwaldia K, Ramos F (2019) Pomegranate and grape by-products and their active compounds: are they a valuable source for food applications. Trends Food Sci Technol 86:68-84. https://doi.org/10.1016/.tiff.2019.02.010

24. Valdés A, Garcia-serna E, Martínez-abad A, Vilaplana F, Jimenez A, Garrigós MC (2020) Gelatin-based antimicrobial films incorporating pomegranate (Punica granatum I.) Seed juice by-product. Molecules 25(1):166-168

25. Rosas-burgos EC, Burgos-hernández A, Noguera-artiaga L, Kačániová M, Hernández-garcía F, Cárdenas-lópez UL (2016) Antimicrobial activity of pomegranate peel extracts as affected by cultivar. J Sci Food Agric 97(93): 802-810

26. Dahham SS, Ali MN, Tabassum H, Khan M (2010) Studies on antibacterial and antifungal activity of pomegranate (Punica granatum I.). Am Eur J Agric Environ Sci 9(3):273-281

27. Klangpetch W, Phromsurin K, Hannarong K, Wichaphon J, Rungchang S (2016) Antibacterial and antioxidant effects of tropical citrus peel extracts to improve the shelf life of raw chicken drumettes. Int Food Res J 23(2):700-707

28. Mostafa AA, Al-askar AA, Almaary KS, Dawoud TM, Sholkamy EN, Bakri MM (2018) Antimicrobial activity of some plant extracts against bacterial strains causing food poisoning diseases. Saudi J Biol Sci 25(2):361-366. https://doi. org/10.1016/j.jjbs.2017.02.004

29. Mueller JH, Hinton J (1941) A protein-free medium for primary isolation of the gonococcus and meningococcus. Proc Soc Exp Biol Med 48(1):330-333. https://doi.org/10.3181/00379727-48-13311

30. Behbahani BA, Fooladi AAI (2018) Evaluation of phytochemical analysis and antimicrobial activities allium essential oil against the growth of some microbial pathogens. Microbial Pathogen 114:299-303

31. Prieto P, Pineda M, Aguilar M (1999) Spectrophotometric quantitation of antioxidant capacity through the formation of a phosphomolybdenum complex: specific application to the determination of vitamin e. Anal Biochem 269(2):337-341. https://doi.org/10.1006/abio.1999.4019

32. Arvouet-grand A, Vennat B, Pourrat A, Legret P (1994) Standardisation d'un extrait de propolis et identification des principaux constituants. J de parmacie de belgique 49:462-468

33. Singleton VL, Orthofer R, Lamuela-raventós RM (1999) Analysis of tota phenols and other oxidation substrates and antioxidants by means of folinciocalteu reagent. Methods Enzymol 299:152-178. https://doi.org/10.1016/ S0076-6879(99)99017-1

34. Katoch $\mathrm{R}$ (2011) Analytical techniques in biochemistry and molecular biology. Springer. https://doi.org/10.1007/978-1-4419-9785-2 
35. Salem MZ, Zayed MZ, Ali HM, Abd El-Kareem SM (2016) Chemical composition, antioxidant and antibacterial activities of extracts from schinusmolle wood branch growing in egypt. J Wood Sci 62(6):548-561. https://doi.org/10.1007/s10086-016-1583-2

36. Al-zoreky NS (2009) Antimicrobial activity of pomegranate (Punica granatum I.) fruit peels. Int J Food Microbiol 134(3):244-248. https://doi.org/10.1016/j. ijfoodmicro.2009.07.002

37. Naziri Z, Rajaian H, Firouzi R (2012) Antibacterial effects of iranian native sour and sweet pomegranate (punica granatum) peel extracts against various pathogenic bacteria. Iran J Vet Res 13(4):282-288

38. Chaudhary A, Rahul SN (2017) Antibacterial activity of Punica granatum (pomegranate) fruit peel extract against pathogenic and drug resistance bacterial strains. Int J Curr Microbiol Appl Sci 6(12):3802-3807. https://doi. org/10.20546/ijcmas.2017.612.437

39. Nozohour Y, Golmohammadi R, Mirnejad R, Fartashvand M (2018) Antibacterial activity of pomegranate (Punica granatum I.) seed and peel alcoholic extracts on Staphylococcus aureus and Pseudomonas aeruginosa isolated from health centers. J Appl Biotechnol Rep 5(1):32-36

40. Mathabe MC, Nikolova RV, Lall N, Nyazema NZ (2006) Antibacterial activities of medicinal plants used for the treatment of diarrhoea in Limpopo province, SouthAfrica. Ethnopharmacol 105(1-2):286-293. https://doi.org/1 0.1016/j.jep.2006.01.029

41. Orak HH, Demirci AŞ, Gümüş T (2011) Antibacterial and antifungal activity of pomegranate (Punica granatum I.cv.) peel. Electr J Environ Agric Food Chem 10(3):1958-1969

42. Khan MSA, Ahmad I (2011) In vitro antifungal, antielastase and antikeratinase activity of essential oils of cinnamomum-, syzygium- and cymbopogon-species against Aspergillus fumigatus and Trichophyton rubrum. Phytomedicine 19(1):48-55. https://doi.org/10.1016/j.phymed.2011.07.005

43. Obioma A, Chikanka AT, Dumo I (2017) Antimicrobial activity of leave extracts of Bryophyllum pinnatum and Aspilia africana on pathogenic wound isolates recovered from patients admitted in University of Port Harcourt Teaching Hospital, Nigeria. Ann Clin Lab Res 5(3):185-189

44. Abakar HOM, Bakhiet SE, Abadi RSM (2017) Antimicrobial activity and minimum inhibitory concentration of Aloe vera sap and leaves using different extracts. J Pharmacogn Phytochem 6(3):298-303

45. Ehiowemwenguan G, Emoghene AO, Inetianbor JE (2014) Antibacterial and phytochemical analysis of banana fruit peel. losr J Pharm 4(8):18-25

46. Al Laham Shaza A, Al Fadel Frdoos M (2014) Antibacterial activity of various plants extracts against antibiotic-resistant Aeromonas hydrophila. Jundishapur J Microbiol 7(7):e11370

47. Prakash B, Sumangala CH, Melappa G, Gavimath C (2017) Evaluation of antifungal activity of banana peel against scalp fungi. Mat Today Proc 4(11): 11977-11983

48. Okwu DE, Awurum AN, Okoronkwo Jl (2007) Phytochemical composition and in vitro antifungal activity screening of extracts from citrus plants against Fusarium oxysporum of Oka plant (Hibiscus esculentus). Pest Technol 1(2):145-148

49. Velázquez-nuñez MJ, Avila-sosa R, Palou E, López-malo A (2013) Antifungal activity of orange (citrus sinensis var. Valencia) peel essential oil applied by direct addition or vapor contact. Food Control 31(1):1-4.

50. Tchinda CF, Voukeng IK, Beng VP, Kuete V (2017) Antibacterial activities of the methanol extracts of albizia adianthifolia, alchornea laxiflora, laportea ovalifolia and three other cameroonian plants against multi-drug resistant gram-negative bacteria. Saudi J Biol Sci 24(4):950-955

51. Yashaswini P, Arvind (2018) Antimicrobial properties of orange (citrus reticulata var. Kinnow) peel extracts against pathogenic bacteria. Int J Curr Microbiol App Sci 7(3):737-746

52. Ozturk B, Parkinson C, Gonzalez-miquel M (2018) Extraction of polyphenolic antioxidants from orange peel waste using deep eutectic solvents. Sep Purif Technol 206:1-13.

53. Kaur S, Kaur S, Gupta AK, Kaur N, Javed M (2014) Biochemical and nutritional characterization of chickpea (cicer arietinum) genotypes. Indian J Agric Sci 84(4):479-486

54. Maniyan A, John R, Mathew A (2015) Evaluation of fruit peels for some selected nutritional and anti-nutritional factors. Emer Life Sci Res 1(2):12-19

55. Ardekani MRS, Hajimahmoodi M, Oveisi MR, Sadeghi N, Jannat B, Ranjbar AM, Moridi T (2011) Comparative antioxidant activity and total flavonoid content of persian pomegranate (punica granatum I.) Cultivars. Iran J Pharm Res 10(3):519-524
56. Jalili S, Tabatabee Naini A, Ashrafi M, Aminlari M (2020) Antioxidant activity of pericarp extract from different varieties of pomegranate fruit. J Agric Sci Technol 22(1):95-107

57. Thitipramote N, Maisakun T, Chomchuen C, Pradmeeteekul P, Nimkamnerd J, Vongnititorn P, Chaiwut P, Thitilertdecha N, Pintathong P (2019) Bioactive compounds and antioxidant activities from pomegranate peel and seed extracts. Food Appl Biosci J 7(3):152-161.

58. M'hiri N, Irina I, Cédric P, Ghoul M, Boudhrioua N (2017) Antioxidants of maltease orange peel: comparative investigation of the efficiency of four extraction methods. J Appl Pharm Sci 7(11)126-135

59. Kanazawa K, Sakakibara H (2000) High content of dopamine, a strong antioxidant, in cavendish banana. J Agric Food Chem 48(3):844-848

60. Someya S, Yoshiki Y, Okubo K (2002) Antioxidant compounds from bananas (musa cavendish). Food Chem 79(3):351-354.

61. Wolfe K, Wu X, Liu RH (2003) Antioxidant activity of apple peels. J Agric Food Chem 51(3):609-614

62. Bonomo MG, Cafaro C, Russo D, Calabrone L, Milella L, Saturnino C, Salzano G (2020) Antimicrobial activity, antioxidant properties and phytochemical screening of aesculus hippocastanum mother tincture against food-borne bacteria. Lett Drug Des Discov 17(1):48-56.

63. Mohammed GJ, Al-jassani M, Hameed $I H$ (2016) antibacterial, antifungal activity and chemical analysis of punica grantanum (pomegranate peel) using gc-ms and ftir spectroscopy. Int J Pharmacognosy Phytochem Res 8(3):480-494

64. Nafea EA, Moselhy WA, Fawzy A (2011) Does the hmf value affect the antibacterial activity of the bee honey? Egyptian academic journal of biological sciences. A, Entomology 4(1):13-19.

65. Teoh YP, Mashitah MD (2016) Extraction of 4h-pyran-4-one, 2,3- dihydro -6-methyl-, an alternative antifungal agent, from schizophyllum commune: optimization and kinetic study. Borneo Sci 37(1):1-22.

66. Hajiabbasi P, Ziarani GM, Badiei A, Soorki AA (2015) Application of sba-prnh2 in one-pot three-component reaction of methylene-carbonyl compounds, acenaphthenequinone, malononitriles and exploration of its antimicrobial activity. J Iran Chem Soc 12(1):57-65

67. Turpaev K, Welsh N (2016) Aromatic malononitriles stimulate the resistance of insulin-producing beta-cells to oxidants and inflammatory cytokines. Eur J Pharmacol 784:69-80.

68. Duru CE, Onuh EF (2018) Fatty acid alkyl esters from vernonia amygdalina leaf extract as potent antibacterial agents. J Chem Soc Niger 43(2):187-194

69. Henslera Mary E, Bernsteina G, Nizeta V, Nefzi A (2006) Pyrrolidine biscyclic guanidines with antimicrobial activity against drug-resistant grampositive pathogens identified from a mixture-based combinatorial library. Bioorg Med Chem Lett 16(19):5073-5079

70. Arslan S, Loğoğlu E, Öktemer A (2006) Antimicrobial activity studies on some piperidine and pyrrolidine substituted halogenobenzene derivatives. J Enzyme Inhib Med Chem 21(2):211-214

\section{Publisher's Note}

Springer Nature remains neutral with regard to jurisdictional claims in published maps and institutional affiliations.

\section{Submit your manuscript to a SpringerOpen ${ }^{\circ}$ journal and benefit from:}

- Convenient online submission

- Rigorous peer review

- Open access: articles freely available online

- High visibility within the field

- Retaining the copyright to your article

Submit your next manuscript at $>$ springeropen.com 